Економічні науки: збірник наукових праць Луиького національного технічного університету. Серія "Регіональна економіка". Випуск 17 (67). Редкол.: відп. ред. к.е.н., професор І.В. Кривов'язюк. Луцьк: ІВВ Луцького НТУ, 2020. 348 с.

УДК 332.155:664.6

Талах Т.А., к.е.н., доцент

Бондарук Х.В., асистент

Хилько О.В.

Луцький національний технічний університет

\title{
НАПРЯМИ УДОСКОНАЛЕННЯ МЕТОДИКИ АНАЛІЗУ ЕФЕКТИВНОСТІ ВИКОРИСТАННЯ АКТИВІВ ПІДПРИЄМСТВА
}

У статті розглянуто напрями удосконалення методики економічного аналізу ефективності використання активів підприємства. Запропоновано розширення аналітичних процедур за допомогою проведення SWOT-аналізу, оптимізації структури активів підприємства та визначення рівня ймовірності банкрутства підприємства на основі показників ефективності використання активів підприємства.

Ключові слова: економічний аналіз, методика, активи, ефективність.

Talakh T., Bondaruk H., Hilko A.

\section{DIRECTIONS OF IMPROVEMENT OF THE METHOD OF ANALYSIS OF EFFICIENCY OF USE OF ASSETS OF THE ENTERPRISE}

Studies on the methodology of analysis and its practical application indicate the need for further study of shortcomings in the work of industrial enterprises and provide recommendations for improving the stages of economic analysis and the use of modern methods of processing economic information. 
Економічні науки: збірник наукових праць Луиького національного технічного університету. Серія "Регіональна економіка". Випуск 17 (67). Редкол.: відп. ред. к.е.н., професор І.В. Кривов’язюк. Луцьк: ІВВ Луцького НТУ, 2020. 348 с.

To identify the main shortcomings in the financial and economic activities of enterprises in general and in the area of asset efficiency, we propose to explore the most important strengths and weaknesses, opportunities and threats to the development of the cardboard and paper industry. It is expedient to carry out by means of SWOT-analysis of the enterprise. SWOT-analysis is a necessary technology for continuous diagnostics of resources and capabilities of enterprises in certain industries.

In order to strengthen the positive factors and neutralize (weaken) the negative, it is necessary to conduct a systematic comprehensive analysis of enterprise assets. This analysis, in our opinion, should provide methodological tools for financing the assets of the enterprise.

The choice of the model of financing the assets of the enterprise is based on the efficiency of the use of assets depending on the level of liquidity and level of profitability. The choice of the model of financing the assets of the enterprise allows the management of the enterprise to make decisions on financial activities, competitiveness and solvency.

The next stage of the analysis we offer the calculation and study of the optimal structure of working capital of the enterprise. When choosing the optimal structure of current assets to be guided by the real capabilities of the enterprise.

One of the conditions for improving the efficiency of the enterprise's assets is its profitability and stable financial condition. To ensure these parameters, we propose to monitor the probability of bankruptcy of the enterprise. This monitoring is carried out according to different systems and models. We offer to use a modern model Turilo A.M, Svyatenko S.V determining the probability of bankruptcy. According to this model, the equation of the probability of bankruptcy includes indicators of the efficiency of the use of enterprise assets - the ratio of absolute liquidity, the ratio of inventories of working capital, return on assets. Therefore, we propose to use this model when analyzing the assets of the enterprise.

Key words: economic analysis, methodology, assets, efficiency.

\section{Талах Т., Бондарук К., Хилько О.В. \\ НАПРАВЛЕНИЯ СОВЕРШЕНСТВОВАНИЯ МЕТОДИКИ АНАЛИЗА ЭФФЕКТИВНОСТИ ИСПОЛЬЗОВАНИЯ АКТИВОВ ПРЕДПРИЯТИЯ}

В статье рассмотрены направления совершенствования методики экономического анализа эффективности использования активов предприятия. Предложено расширение аналитических процедур посредством проведения SWOT-анализа, оптимизации структуры активов предприятия и определения уровня вероятности банкротства предприятия на основе показателей эффективности использования активов предприятия.

Ключевые слова: экономический анализ, методика, активы, эффективность. 
Економічні науки: збірник наукових праць Луиького національного технічного університету. Серія "Регіональна економіка". Випуск 17 (67). Редкол.: відп. ред. к.е.н., професор І.В. Кривов'язюк. Луиьк: ІВВ Луцького НТУ, 2020. 348 с.

Постановка проблеми у загальному вигляді і її зв'язок 3 важливими науковими та практичними завданнями. Для сучасної національної економіки характерна нестабільність і висока динамічність зовнішнього середовища. Всі ці чинники негативно впливають на фінансовий стан підприємства i змушують його керівників постійно приймати рішення в умовах невизначеності. Внаслідок цього на перший план виходять фінансові аспекти діяльності підприємства. Одним 3 таких аспектів $є$ ефективність використання активів підприємства i підтримання їх на достатньому рівні.

Вивчення методики аналізу ефективності використання активів підприємства та удосконалення підходів щодо його здійснення на сучасному етапі $€$ важливим питанням для картонно-паперової галузі національної економіки, оскільки постає питання економі їх матеріальних активів, ефективного використання та пошуку шляхів розвитку ринку вторинної сировини. Підприємства надалі продовжують вкладати немалі інвестиції в розвиток системи заготівлі макулатури в Україні. Нажаль, сьогодні для підприємств відчувається реальний дефіцит макулатури. Введення в експлуатацію додаткових потужностей, звичайно, призведе до зростання споживання i подальшого збільшення дефіциту макулатури. Вищевикладене зумовлює актуальність теми дослідження.

Аналіз останніх досліджень, у яких започатковано вирішення проблеми. Теоретичні засади формування та використання активів підприємства викладені у працях Ф. Кене, А. Маршала, Дж. Ст. Мілля, А. Сміта, С. Фішера, Й. Шумпетера. Вагомий внесок у сучасну економічну теорію i практику формування та ефективного використання активів підприємства зробили вітчизняні й зарубіжні економісти Бланк I.O., Коваленко Л.О., Крамаренко Г.О., Василенко Л.П., Загородній А.Г., Вознюк Г.Л., Ремньова Л.М., Чорна О.С., Стоянова Є.С. та ін

Цілі статті. Зважаючи на вищесказане, метою даної статті $\epsilon$ вивчення напрямів удосконалення методики аналізу 
Економічні науки: збірник наукових праць Луиького національного технічного університету. Серія "Регіональна економіка". Випуск 17 (67). Редкол.: відп. ред. к.е.н., професор І.В. Кривов’язюк. Луцьк: ІВВ Луцького НТУ, 2020. 348 с.

ефективності використання активів підприємства та практичне їх застосування.

Виклад основного матеріалу дослідження 3 повним обгрунтуванням отриманих наукових результатів.

Проведені дослідження з методики аналізу та практичного iii застосування вказують на необхідності подальшого вивчення недоліків в роботі підприємств промисловості та надання рекомендацій по удосконаленню етапів проведення економічного аналізу і використання сучасних методів обробки економічної інформації.

Для виявлення основних недоліків у фінансовогосподарській діяльності підприємств в цілому і на ділянці ефективності використання активів ми пропонуємо дослідити найбільш важливі сильні та слабкі сторони, можливості та загрози розвитку підприємств картонно-паперової промисловості. Це доцільно провести за допомогою SWOTаналізу підприємства. SWOT-аналіз є необхідною технологією проведення постійної діагностики ресурсів та можливостей підприємств певних галузей. Суть даного дослідження полягає в поділі чинників та явищ, що впливають на функціонування та розвиток підприємств на чотири категорії: strengths (сильні сторони), weaknesses (слабкі сторони), opportunities (можливості), threats (загрози).

Після проведення аналізу сильних та слабких сторін підприємства, а також загроз та можливостей зовнішнього середовища, зобразимо матрицю SWOT-аналізу (табл. 1). 3 проведеного SWOT-аналізу підприємств картонно-паперової промисловості України можна сказати, що перетворивши слабкі сторони в сильні, підприємство зможе підвищити свою ефективність та розвиватися на майбутнє. 
Економічні науки: збірник наукових праць Луиького начіонального технічного університету. Серія "Регіональна економіка". Випуск 17 (67). Редкол.: відп. ред. к.е.н., професор І.В. Кривов’язюк. Луцьк: ІВВ Луцького НТУ, 2020. 348 с.

\section{Таблиця 1}

\section{Матриця SWOT-аналізу середовища підприємств} картонно-паперової промисловості України

\begin{tabular}{|c|c|c|}
\hline & $\begin{array}{l}\text { Можсливості } \\
\text { - пошук нових } \\
\text { постачальників } \\
\text { екологічно-чистої } \\
\text { натуральної сировини; } \\
\text { - збільшення вироб- } \\
\text { ничих площ та } \\
\text { потужностей; } \\
\text { - пошук нових ринків } \\
\text { збуту продукції. }\end{array}$ & $\begin{array}{l}\text { Загрози: } \\
\text { - не певна економічна } \\
\text { ситуація в країні; } \\
\text { - висока конкурентна } \\
\text { боротьба на ринку } \\
\text { збуту продукції; } \\
\text { - зростання цін на } \\
\text { натуральну сировину } \\
\text { для в виробництва } \\
\text { продукції. }\end{array}$ \\
\hline \begin{tabular}{l}
\multicolumn{3}{c}{ Сильні сторони } \\
- широкий асортимент \\
продукції; \\
- виробництво екологічно- \\
чистої продукції; \\
- висока ефективність \\
реклами; \\
- ефективне ціноутворення, \\
яке направлене на \\
кінцевого $\quad$ споживача \\
продукції; \\
- висококваліфікована \\
робоча сила; \\
- висока \\
підприємства. потужність \\
\end{tabular} & 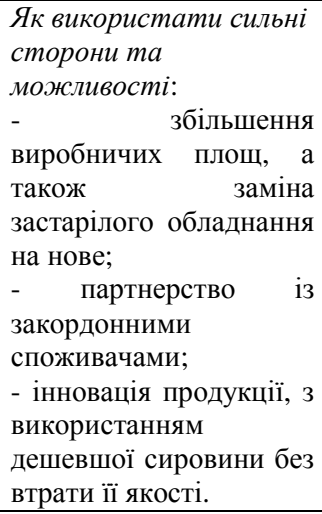 & \begin{tabular}{lr}
\multicolumn{2}{r}{ Як використати } \\
сильні сторони та \\
зменшити \\
загроз: \\
- вплив \\
рекламної політики \\
акцентом \\
інновацію, \\
уникнення \\
$\begin{array}{l}\text { появи } \\
\text { конкурентів. }\end{array}$ \\
метою \\
ризику \\
нових \\
\end{tabular} \\
\hline $\begin{array}{l}\text { Слабкі сторони } \\
\text { - висока вартість } \\
\text { екологічно-чистої } \\
\text { натуральної сировини; } \\
\text { - імпорт натуральної } \\
\text { сировини за високими } \\
\text { цінами; } \\
\text { - велика конкуренція на } \\
\text { ринку картонно-паперової } \\
\text { продукції; } \\
\text { - не достатня вітчизняна } \\
\text { база макулатури. }\end{array}$ & 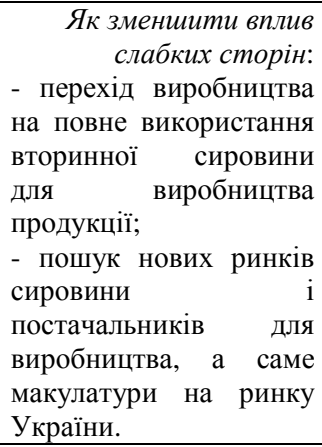 & $\begin{array}{r}\text { Як зменшити вплив } \\
\text { слабких сторін та } \\
\text { перетворити загрози в } \\
\text { можливості: } \\
\text { - заміна застарілого } \\
\text { обладнання; } \\
-\quad \text { енергоощадне } \\
\text { виробництво; } \\
-\quad \text { безвідходне } \\
\text { виробництво. }\end{array}$ \\
\hline
\end{tabular}

Серед актуальних проблем галузі $є$ недостатнє, дороге сировинне забезпечення виробництва картонно-паперової продукції. Обсяг імпортованих відходів паперу та картону та 
Економічні науки: збірник наукових праць Луиького національного технічного університету. Серія "Регіональна економіка". Випуск 17 (67). Редкол.: відп. ред. к.е.н., професор І.В. Кривов'язюк. Луиьк: ІВВ Луцького НТУ, 2020. 348 с.

разом 3 ним i витрати на імпортну макулатуру стрімко збільшуються. На заготівельних пунктах ціна макулатури коливається і залежить від обсягу відходів, розміру міста та інших факторів. Приблизна ціна одного кілограму макулатури на пунктах прийому - 2,50 грн. (2500 грн за тонну). Однак, вартість макулатури на паперових комбінатах, враховуючи іï перевезення та доставку, значно зростає. Тому сьогодні першочерговим завданням $є$ забезпечення розвитку ринку вторинної сировини, тобто макулатури (це основний вид сировини для досліджуваної галузі).

3 метою посилення дії позитивних факторів та нейтралізації (послаблення) негативних, необхідно проводити систематичний комплексний аналіз активів підприємства. Цей аналіз, на нашу думку, повинен забезпечувати методичний інструментарій фінансування активів підприємства.

Вибір моделі фінансування активів підприємства здійснюється за показниками ефективності використання активів залежно від рівня ліквідності та рівня рентабельності. При ідеальній моделі фінансування активів підприємство має низький рівень ліквідності i рентабельності, при цьому виникають ризики нестачі або надлишку коштів і нестачі або надлишку кредитів. При виборі агресивної моделі у підприємства спостерігається високий рівень ліквідності та низька рентабельність, при цьому можуть виникнути ризики нестачі (надлишку) коштів у підприємства. Консервативна модель передбачає низький рівень ліквідності та високий рівень рентабельності і можливість нестачі (надлишку) кредитів банку. Компромісна модель передбачає високий рівень ліквідності і рентабельності, а також ризики нестачі (надлишку) коштів та кредитів підприємства.

На основі таблиці 1 досліджено, що ПрАТ «Київський картонно-паперовий комбінат», який за три останні роки має низький рівень ліквідності (жоден показник не відповідає рекомендаційному рівню) та високий рівень рентабельності. Тобто підприємству притаманна консервативна модель фінансування активів підприємства. При цьому причиною не 
Економічні науки: збірник наукових праць Луиького начіонального технічного університету. Серія "Регіональна економіка". Випуск 17 (67). Редкол.: відп. ред. к.е.н., професор І.В. Кривов’язюк. Луцьк: ІВВ Луцького НТУ, 2020. 348 с.

достатності фінансування може бути високий рівень кредиторської заборгованості.

ТОВ «Володимирська фабрика гофротари» за даними таблиці 2 керується комбінованою моделлю фінансування активів, оскільки за два остання роки має високий рівень показників ліквідності та рентабельності. Тобто на підприємстві оптимальне співвідношення між короткостроковими та довгостроковими джерелами позикових коштів та є в постійній наявності грошові кошти. Ця модель характеризується тим, що в окремі періоди підприємство може мати надлишкові обсяги запасів і грошових коштів.

Таблиця 2

Динаміка показників ліквідності та рентабельності підприємств картонно-паперової промисловості за 2017-2019 рр., \%

\begin{tabular}{|c|c|c|c|c|c|c|c|c|c|}
\hline \multirow[t]{2}{*}{ Показник } & \multicolumn{3}{|c|}{$\begin{array}{c}\text { ПрАТ «Київський } \\
\text { картонно-паперовий } \\
\text { комбінат» }\end{array}$} & \multicolumn{3}{|c|}{$\begin{array}{l}\text { ТОВ «Володимирська } \\
\text { фабрика гофротари» }\end{array}$} & \multicolumn{3}{|c|}{ ПрАТ «ВГП» } \\
\hline & $\begin{array}{c}2017 \\
\text { рік }\end{array}$ & $\begin{array}{c}2018 \\
\text { рік }\end{array}$ & $\begin{array}{c}2019 \\
\text { рiк }\end{array}$ & $\begin{array}{c}2017 \\
\text { рік }\end{array}$ & $\begin{array}{c}2018 \\
\text { рік }\end{array}$ & $\begin{array}{c}2019 \\
\text { рік }\end{array}$ & $\begin{array}{c}2017 \\
\text { рік }\end{array}$ & $\begin{array}{c}2018 \\
\text { рік }\end{array}$ & $\begin{array}{l}2019 \\
\text { рік }\end{array}$ \\
\hline $\begin{array}{l}\text { Загальний } \\
\text { коефіцієнт } \\
\text { ліквідності }\end{array}$ & 0,76 & 0,87 & 0,91 & 1,07 & 2,55 & 2,93 & 1,17 & 1,22 & 1,52 \\
\hline $\begin{array}{l}\text { Коефіцієнт } \\
\text { термінової } \\
\text { ліквідності }\end{array}$ & 0,38 & 0,46 & 0,53 & 0,66 & 0,58 & 0,77 & 0,61 & 0,44 & 0,60 \\
\hline $\begin{array}{l}\text { Коефіцієнт } \\
\text { абсолютної } \\
\text { ліквідності }\end{array}$ & 0,02 & 0,03 & 0,34 & 0,01 & 0,03 & 0,04 & 0,00 & 0,00 & 0,00 \\
\hline $\begin{array}{l}\text { Рентабельність } \\
\text { (збитковість) } \\
\text { продажів, \% }\end{array}$ & 5,5 & 6,8 & 7,0 & $(66,6)$ & 5,3 & 11,6 & $(28,5)$ & $(18,4)$ & $(13,0)$ \\
\hline $\begin{array}{l}\text { Рентабельність } \\
\text { (збитковість) } \\
\text { продукції } \\
\text { підприємства, \% }\end{array}$ & 7,4 & 8,9 & 8,8 & $(59,5)$ & 6,1 & 14,0 & $(45,1)$ & $(31,0)$ & $(22,5)$ \\
\hline $\begin{array}{l}\text { Рентабельність } \\
\text { активів, \% }\end{array}$ & 8,6 & 10,3 & 9,7 & $-17,5$ & 3,5 & 8,7 & $-22,1$ & $-18,2$ & $-11,9$ \\
\hline
\end{tabular}

ПрАТ «ВГП» за останні три роки було збитковим, тому показники рентабельності (збитковості) дуже низькі і показники ліквідності знаходяться до межі рекомендованого значення. Тому цьому підприємству притаманне ідеальна модель фінансування активів підприємства, оскільки на підприємстві 
Економічні науки: збірник наукових праць Луиького національного технічного університету. Серія "Регіональна економіка". Випуск 17 (67). Редкол.: відп. ред. к.е.н., професор І.В. Кривов’язюк. Луцьк: ІВВ Луцького НТУ, 2020. 348 с.

недостатньо грошових коштів та власних кредитних можливостей. Ця форма фінансування передбачає, що довгострокові зобов'язання є джерелами покриття необоротних активів; оборотні активи дорівнюють поточним зобов'язання і чисті оборотні активи дорівнюють нулю.

Таким чином, вибір моделі фінансування активів підприємства дає можливість керівництву підприємства приймати рішення щодо фінансової діяльності, конкурентоспроможності та платоспроможності.

Наступним етапом аналізу ми пропонуємо розрахунок та дослідження оптимальної структури оборотних засобів підприємства. Одним із основних критеріїв ефективності господарювання $є$ рівень своєчасності розрахунків підприємства за своїми короткостроковими зобов'язаннями, тобто відповідний рівень ліквідності (табл. 3).

Таблиця 3

Структура оборотних активів за різних значень коефіцієнта загальної ліквідності

\begin{tabular}{|c|c|c|c|c|}
\hline \multirow{2}{*}{ Показник } & \multicolumn{3}{|c|}{$\begin{array}{c}\text { Значення коефіцієнта покриття } \\
\text { (коефіцієнт загальної ліквідності })\end{array}$} \\
\cline { 2 - 6 } & $\begin{array}{c}\text { Кз.л.= } \\
2,93 \\
(2019 \text { рік) }\end{array}$ & $\begin{array}{c}\text { Кз.л.= } \\
1,5\end{array}$ & $\begin{array}{c}\text { Кз.л.= } \\
2,0\end{array}$ & $\begin{array}{c}\text { Кз.л.= } \\
2,5\end{array}$ \\
\hline $\begin{array}{l}\text { Частка запасів у структурі } \\
\text { оборотних активів, \% }\end{array}$ & 76,3 & 54 & 65 & 72 \\
\hline $\begin{array}{l}\text { Частка дебіторської заборгованості } \\
\text { у структурі оборотних активів, \% }\end{array}$ & 21,8 & 33 & 25 & 20 \\
\hline $\begin{array}{l}\text { Частка високоліквідних активів у } \\
\text { структурі оборотних активів, \% }\end{array}$ & 1,07 & 13 & 10 & 8 \\
\hline
\end{tabular}

Для дослідження обираємо ТОВ «Володимирська фабрика гофротари», оскільки на цьому підприємстві коефіцієнт загальної ліквідності (коефіцієнт покриття) перевищує рекомендоване значення, а отже у підприємства створено понаднормативний запас матеріальних цінностей, які не використовуються у виробничому процесі. Тому розрахунок 
Економічні науки: збірник наукових праць Луиького національного технічного університету. Серія "Регіональна економіка". Випуск 17 (67). Редкол.: відп. ред. к.е.н., професор І.В. Кривов’язюк. Луцьк: ІВВ Луцького НТУ, 2020. 348 с.

оптимальної структури оборотних активів є актуальним для цього підприємства.

В табл. 3 представлено оптимізацію структури оборотних активів за різних значень коефіцієнта загальної ліквідності. Як бачимо досліджуване підприємство фактично за 2019 рік не має оптимальної структури оборотних засобів.

Розрахунок обсягу оборотних активів та їх елементів за різними структурами у відповідності до коефіцієнта загальної ліквідності для ТОВ «Володимирська фабрика гофротари» представлено у табл. 4.

Таблиця 4

Розрахунок обсягу оборотних активів ТОВ «Володимирська фабрика гофротари» за різними варіантами оптимізації їх структури

\begin{tabular}{|l|c|c|c|c|}
\hline \multirow{2}{*}{ Показник } & \multicolumn{4}{|c|}{ Значення коефіцієнта покриття (коефіцієнт } \\
\cline { 2 - 5 } & $\begin{array}{c}\text { Кз.л.=2,93 } \\
\text { (2019 рік) }\end{array}$ & Кз.л.=1,5 & Кз.л.=2,0 & Кз.л.=2,5 \\
\hline $\begin{array}{l}\text { 1.Оборотні активи, тис. } \\
\text { грн - всього, в т.ч. }\end{array}$ & 13851 & 6720,3 & 8960,4 & 11200,5 \\
\hline - запаси & 9986 & 3629,0 & 5824,3 & 8064,4 \\
\hline $\begin{array}{l}\text { - дебіторська } \\
\text { заборгованість }\end{array}$ & 3691 & 2217,7 & 2240,1 & 2240,1 \\
\hline $\begin{array}{l}\text { гроші та поточні } \\
\text { фінансові інвестиції }\end{array}$ & 174 & 873,6 & 896,0 & 896,0 \\
\hline $\begin{array}{l}\text { 2. Коефіцієнт швидкої } \\
\text { ліквідності }\end{array}$ & 0,774 & 0,69 & 0,7 & 0,7 \\
\hline $\begin{array}{l}\text { 3. Коефіцієнт абсолютної } \\
\text { ліквідності }\end{array}$ & 0,037 & 0,2 & 0,2 & 0,2 \\
\hline
\end{tabular}

Ми пропонуємо, під час вибору оптимальної структури оборотних активів керуватися реальними можливостями підприємства. Граничне (рекомендаційне) значення коефіцієнта загальної ліквідності - 2,0-2,5. Якщо обрати варіант, де коефіцієнт загальної ліквідності рівний 1,5 , то підприємству необхідно за цих умов скоротити обсяг запасів більше ніж у 3 рази, що може призвести до зупинки виробничого процесу. Якщо обрати варіант, коли коефіцієнт загальної ліквідності 
Економічні науки: збірник наукових праць Луиького національного технічного університету. Серія "Регіональна економіка". Випуск 17 (67). Редкол.: відп. ред. к.е.н., професор І.В. Кривов'язюк. Луиьк: ІВВ Луцького НТУ, 2020. 348 с.

рівний 2,5, то необхідно значно нарощувати обсяг грошових коштів i фінансових інвестицій, тому обираємо варіант оптимальної структури при коефіцієнті покриття, який рівний 2.

За цим варіантом Товариству необхідно скоротити залишки оборотних активів на 31,7 \%, з них скоротити залишки запасів на 41,9\% та дебіторської заборгованості на 24,6\%. Це дасть підприємству сформувати ефективну систему контролю за своєчасною оплатою дебіторської заборгованості, запровадити систему знижок у разі вчасного розрахунку за дебіторською заборгованістю, систему часткової або повної передплати новим покупцям за постачання продукції та здійснювати постійний моніторинг рівня їх платоспроможності на підставі їх публічної фінансової звітності.

Однією із умов підвищення рівня ефективності використання активів підприємства $є$ його прибутковість та стійкий фінансовий стан. Для забезпечення цих параметрів ми пропонуємо проводити моніторинг ймовірності банкрутства підприємства. Цей моніторинг здійснюють за різними системами і моделями. Ми пропонуємо скористатися сучасною моделлю Турило А.М., Святенко С.В. визначення ймовірності банкрутства [4]. За цією моделлю в рівняння ймовірності банкрутства входять показники ефективності використання активів підприємства - коефіцієнт абсолютної ліквідності, коефіцієнт забезпеченості запасів власним оборотним капіталом, рентабельність активів. Тому ми пропонуємо, під час аналізу активів підприємства скористатися цією моделлю. Вона має вигляд:

$$
S=5 \cdot X_{1}+2 \cdot X_{2}+1 \cdot X_{3}+5 \cdot X_{4}+6,67 \cdot X_{5},
$$

де $\mathrm{X}_{1}$ - коефіцієнт абсолютної ліквідності;

$\mathrm{X}_{2}$ - коефіцієнт автономії;

$\mathrm{X}_{3}$-відношення власних оборотних коштів до запасів;

$\mathrm{X}_{4}$ - рентабельність продукції за операційним прибутком;

$\mathrm{X}_{5}$ - рентабельність активів за чистим прибутком. 
Економічні науки: збірник наукових праць Луиького національного технічного університету. Серія "Регіональна економіка". Випуск 17 (67). Редкол.: відп. ред. к.е.н., професор І.В. Кривов’язюк. Луцьк: ІВВ Луцького НТУ, 2020. 348 с.

Критерії ідентифікації кризового стану на промислових підприємствах наведено в табл. 5.

Таблиця 5

Критерії оцінки ймовірності банкрутства [4]

\begin{tabular}{|c|c|}
\hline Критерії & Інтерпретачія \\
\hline $\mathrm{S} \geq 5,00$ & Низька ймовірність банкрутства \\
\hline $3,00 \leq \mathrm{S}<5,00$ & Можлива ймовірність банкрутства \\
\hline $1,00 \leq \mathrm{S}<3,00$ & Висока ймовірність банкрутства \\
\hline$-2,00 \leq \mathrm{S}<1,00$ & Дуже висока ймовірність банкрутства \\
\hline $\mathrm{S}<-2,00$ & Підприємство повинне бути \\
ліквідоване
\end{tabular}

Рівняння ймовірності банкрутства для ПрАТ «Київський картонно-паперовий комбінат» за 2019 рік:

$S=5 * 0,338+2 * 0,379+1 *(-0,524)+5 * 0,147+6,67 * 0,097=3,306$

Отже, результат розрахунку знаходиться у межах [3-5], тому підприємству загрожує можлива ймовірність банкрутства за рахунок низького рівня власних оборотних коштів. Підприємство немає в своєму розпорядженні таких засобів i змушене працювати із зовнішнім фінансуванням.

Рівняння ймовірності банкрутства для ТОВ «Володимирська фабрика гофротари» за 2019 рік:

$S=5 * 0,037+2 * 0,426+1 *(-2,084)+5 * 0,256+6,67 * 0,087=-0,467$

Рівняння ймовірності банкрутства для ПрАТ «ВГП» за 2019 рік:

$$
S=5 * 0,111+2 * 0,058+1 *(-3,705)+5 * 0,278+6,67 * 0=-1,644
$$

Таким чином, ці два підприємства знаходяться в зоні дуже високої ймовірності банкрутства за рахунок нестачі власного оборотного капіталу та збитковості активів підприємства.

Результати проведених розрахунків показали, що підприємства картонно-паперової промисловості, що 
Економічні науки: збірник наукових праць Луиького національного технічного університету. Серія "Регіональна економіка". Випуск 17 (67). Редкол.: відп. ред. к.е.н., професор І.В. Кривов’язюк. Луцьк: ІВВ Луцького НТУ, 2020. 348 с.

досліджуються мають різні моделі фінансування активів підприємства, потребують оптимізації структури активів підприємства та мають високий рівень ймовірності банкрутства

Висновки. Особливе місце в системі комплексного економічного аналізу займає дослідження ефективності використання активів підприємства. Пропонується методику аналізу доповнити проведенням SWOT- аналізу, який дозволить виділити позитивні і негативні чинники, що впливають на рівень активів та можливості і загрози зниження ефективності їх використання. Доповнено методику аналізу шляхом оптимізації структури активів підприємства і вибору моделі фінансування активів, а також визначення рівня ймовірності банкрутства підприємства.

\section{Список бібліографічного опису}

1.Ковальчук Н.О. Теоретичні аспекти аналізу складу, структури активів та джерел їх фінансування. Інвестиції: практика та досвід № 23/2019

2.Лотюк М.В. Управління активами підприємства «Економічні студї»» № 1 (14) 2017

3.Степанюк О.С. Оцінювання ефективності використання оборотних активів нафтогазовидобувних підприємств. : автореф. дис. ... канд. економ. наук: 08.00.04. Ів. Франківськ 2020. 22 с.

4.Турило А.М., Святенко С.В. Інформаційна логіко-економічна модель прогнозування кризових явищ на промислових підприємствах України. Актуальні проблеми економіки. 2011. № 10

\section{References}

1. Koval'chuk N.O. (2019) Teoretychni aspekty analizu skladu, struktury aktyviv ta dzherel yikh finansuvannya. [Theoretical aspects of the analysis of the composition, structure of assets and sources of their financing.] Investytsiyi: praktyka ta dosvid № 23/2019. [in Ukrainian]

2. Lotyuk M.V. (2017) Upravlinnya aktyvamy pidpryyemstva [Asset Management] Ekonomichni studiyi № 1 (14) 2017. [in Ukrainian]

3. Stepanyuk O.S.(2020) Otsinyuvannya efektyvnosti vykorystannya oborotnykh aktyviv naftohazovydobuvnykh pidpryyemstv. [Evaluation of the efficiency of the use of current assets of oil and gas companies]: avtoref. dys. ... kand. ekonom. nauk: 08.00.04. Iv. Frankivs'k 2020. 22 s. . [in Ukrainian]

4. Turylo A.M., Svyatenko S.V. (2011) Informatsiyna lohiko-ekonomichna model' prohnozuvannya kryzovykh yavyshch na promyslovykh pidpryyemstvakh Ukrayiny.[ Information logical-economic model of crisis forecasting at industrial enterprises of Ukraine.] Aktual'ni problemy ekonomiky. 2011. № 10 [in Ukrainian] 